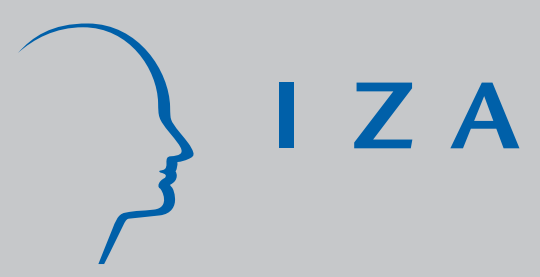

IZA DP No. 3268

Who Leaves and Who Returns? Deciphering Immigrant Self-Selection from a Developing Country

Randall K. Q. Akee

December 2007 


\title{
Who Leaves and Who Returns? Deciphering Immigrant Self-Selection from a Developing Country
}

\author{
Randall K. Q. Akee
}

IZA

Discussion Paper No. 3268

December 2007

\author{
IZA \\ P.O. Box 7240 \\ 53072 Bonn \\ Germany
}

Phone: +49-228-3894-0
Fax: +49-228-3894-180
E-mail: iza@iza.org

Any opinions expressed here are those of the author(s) and not those of the institute. Research disseminated by IZA may include views on policy, but the institute itself takes no institutional policy positions.

The Institute for the Study of Labor (IZA) in Bonn is a local and virtual international research center and a place of communication between science, politics and business. IZA is an independent nonprofit company supported by Deutsche Post World Net. The center is associated with the University of Bonn and offers a stimulating research environment through its research networks, research support, and visitors and doctoral programs. IZA engages in (i) original and internationally competitive research in all fields of labor economics, (ii) development of policy concepts, and (iii) dissemination of research results and concepts to the interested public.

IZA Discussion Papers often represent preliminary work and are circulated to encourage discussion. Citation of such a paper should account for its provisional character. A revised version may be available directly from the author. 


\title{
ABSTRACT
}

\section{Who Leaves and Who Returns? Deciphering Immigrant Self-Selection from a Developing Country ${ }^{*}$}

\begin{abstract}
Existing research examining the self-selection of immigrants suffers from a lack of information on the immigrants' labor force activities in the home country, quotas limiting who is allowed to enter the destination country, and non-economic factors such as internal civil strife in the home country. Using a novel data set from the Federated States of Micronesia (FSM), I analyze a migration flow to the U.S. that suffers from none of these problems. I find that high-skilled workers (relative to the home country skill distribution) are the most likely to migrate from the FSM to the U.S. and that their behavior is explained mainly by the difference in average wages for their skill group. This finding suggests that previous immigration studies have overemphasized the role played by differences in the distributions of countries' wages and skills. Including information on the immigrants' characteristics prior to migration is central to my analysis, which highlights the importance of datasets that contain both home and destination country data on immigrants. Given the home country information, I use weather shocks to predict the probability of outmigration, which overcome the usual endogeneity problems in determining self-selection of immigrants. Second, I conduct nearest neighbor matching for immigrants prior to their leaving the home country using home country wages as the outcome variable to determine the nature of selection on unobservable characteristics.
\end{abstract}

JEL Classification: $\quad 015, \mathrm{~J} 31$

Keywords: immigration, developing country, self-selection

Corresponding author:

Randall Akee

IZA

P.O. Box 7240

D-53072 Bonn

Germany

E-mail: akee@iza.org

\footnotetext{
* I am grateful to George Borjas, Ana Rute Cardoso, Joyce Chen, Charles Cohen, David Evans, Erica Field, Caroline Hoxby, Lakshmi lyer, Larry Katz, Michael Kremer, Sonal Pandya, Bruce Sacerdote, Raven Saks, Matthias Schuendeln, Matthew Snipp, Catherine Thomas, Rebecca Thornton, Robert Urbatsch, William Ward, Jeffrey Williamson, Lehua Yim and seminar participants at the Harvard Economics Development, Econometrics, and Labor Lunches. I give special thanks to Richard Freeman, Devesh Kapur, Sendhil Mullainathan and Mark Rosenzweig for their insight on this project. I am especially indebted to the FSM Statistics Office in Kolonia, Micronesia. Providing invaluable assistance were Eneriko Suldan of the Statistics Office, Michael Levin of the US Census Bureau and Bill Raynor of the Nature Conservancy. Any errors, omissions, or oversights are my own.
} 


\section{Introduction}

International migration has increased across the world in the past few decades. Between 1960 and 2000, the percent of the world population categorized as international migrants increased from 2.5\% to $2.9 \%{ }^{1}$ This increase is even larger for places like the United States which saw the percentage of foreign born increase from 5.6\% in 1970 to $12.9 \%$, or about 35 million foreign immigrants, in 2000 . (IOM, 2005) This upward trend shows no sign of slowing down in the coming decades. Despite the magnitude and importance of this growing trend, many fundamental economic questions remain unanswered.

Who leaves a developing country for a developed country? The answer to this question is determined by a number of complex factors. Individuals must consider their future opportunities at home and in the destination countries. The costs to migration are also important factors in this decision process. These costs may be direct transportation costs or they may be cultural or linguistic barriers at the destination. Finally, there are legal impediments that severely restrict the composition and size of immigration flows into all developed countries. The relative magnitude of each of these considerations will greatly influence which sub-group from the home country finds it optimal to migrate. Determining the contribution of each of these factors is important in understanding a very fundamental economic decision-making process.

Uncovering the nature of immigrant self-selection is equally important for policymaking. Immigration policies are formed in response to the changing composition of immigrant flows from developing countries. Fears about the low skill levels of immigrants to developed countries and the impact of these low skilled immigrants on native-born workers shape immigration restrictions. ${ }^{2}$ In the sending countries, the outflow of individuals can affect the levels of income inequality or the prospects for economic development. Migration of low skilled individuals abroad may serve as an important safety

\footnotetext{
${ }^{1}$ International migrants are individuals who live in a different country from the one in which they were born. This increase in level terms is a change from 76 million immigrants in 1970 to 175 million immigrants in 2000. (International Organization for Migration, 2005)

${ }^{2}$ See, for example, Hatton and Williamson (2004) or Goldin (1994)
} 
valve for poor countries, reducing the burden on poor families and countries. Alternatively, an outflow of extremely skilled individuals, the so-called "Brain Drain” phenomenon, can reduce the human capital available to build useful institutions and businesses in the home economy. ${ }^{3}$

The question of who leaves a developing country, therefore, has a profound impact on our understanding of the decision-making process of economic actors as well as on the development of economic policies. The most basic question in this literature asks: are immigrants drawn from the higher or lower end of the skill distribution in the home country? Answering the question, however, has not been straightforward. ${ }^{4}$ Data problems plague immigration research. Generally, there are data available for immigrants in the destination country in census and other survey data; however, there is almost no information regarding an immigrant's labor force status, income level or education level in the home country. Therefore, it is impossible to make meaningful comparisons between newly arrived immigrant cohorts and home country populations.

Previous research, relying on cross-section data, has assumed that immigrants employed in the wage sector abroad are also drawn from the wage sector in the home country. Ramos (1991) tested the nature of self-selection of immigrants from Puerto Rico using 1980 Census data from both the US and Puerto Rico. Ramos compares Puerto Rican immigrants in the US who are employed in the wage sector to Puerto Ricans who never left Puerto Rico and are currently employed in the wage sector. Due to limitations in the available data, it is impossible to know whether the Puerto Rican immigrants in the US were drawn from the wage sector, self-employed sector or were out of the labor force within the Puerto Rican economy. It is highly likely that a large proportion of the Puerto Rican immigrants to the US were drawn from the out of labor force or self-employed sector. ${ }^{5}$ If there are systematic differences in ability

\footnotetext{
${ }^{3}$ See, for example, Kapur and McHale(2005) or Bhagwati and Rodriguez (1976)

${ }^{4}$ Previous work on this topic include: Chiswick (1978) using US cohort data finds immigrants overtaking native born workers after 10-15 years in the US. Borjas (1987) provides evidence for negative selection of immigrants to the US. Chiquiar and Hanson (2005) find evidence for positive selection on observable characteristics of Mexican immigrants to the US.

${ }^{5}$ Approximately $46 \%$ of the adult male population in the 1980 Puerto Rico Census was classified as out of the labor force; furthermore, approximately $10 \%$ of the labor force participants were self-employed and are also excluded from analysis in the Ramos (1991) study.
} 
and education between these three sectors, then any analysis that fails to account for these differences will be biased.

Attempts to remedy these problems have relied on recall data of immigrants. ${ }^{6}$ While these endeavors have their own limitations such as the accuracy of reporting, this is generally an improvement on using single cross-section data sets. The availability and use of data with immigrant recall information is starting to increase in immigration research.

In this paper, I take a more direct approach. I follow the same individual who migrated from the Federated States of Micronesia (FSM), an independent nation-state in the western Pacific, to the US in the time period 1995-1997. To my knowledge, this is the first study which analyzes a complete, unrestricted migration flow and contains data on the immigrants in both the home and destination countries. ${ }^{7}$ This $^{-1}$ research links individuals between two separate data sets, the 1994 FSM Census of Population and Housing and the 1997 Micronesian Immigrant Survey conducted in Hawaii and Guam. The panel nature of this data, in conjunction with the fact that the FSM citizens have no entry barriers or length of stay restrictions into the US, provides a nearly perfect situation to test the direction of self-selection of both observable and unobservable characteristics of these immigrants relative to their appropriate home country reference group. ${ }^{8}$ The two datasets contain information on labor force characteristics, income levels and education levels in the home country for all of the migrants prior to leaving their home country; this information allows me to overcome the usual obstacles and avoid incorrect comparisons present in other immigration research.

\footnotetext{
${ }^{6}$ See, for example, Cerrutti and Massey (2001). See, also, Jasso and Rosenzweig (2005) who utilize the New Immigrant Survey, a panel survey of new legal immigrants to the U.S. which contains data on immigrants' pre and post-migration labor market conditions and education levels (http://nis.princeton.edu/ )

${ }^{7}$ McKenzie et. al (2006) look at selection and its impact on earnings where a lottery exists for migration from Tonga to New Zealand.

${ }^{8}$ The FSM and the US have a Compact of Free Association (1986) which permits unrestricted entry of FSM citizens into the US. In some ways given the freedom from entry restrictions, this migration flow is similar to that of internal migration in a large, developed country. However, the striking difference between these two research areas, internal migration and international migration without entry restrictions, is that the difference in average wages and costs of living differs dramatically and that there should be independence of overall economic conditions between the origin and destination. See Greenwood (1997) for an overview of internal migration research and Saks and Wozniak (2007) for a discussion of how internal migration is strongly procyclical with the business cycle in the US.
} 
I investigate the direction of self-selection based on observable characteristics for employment migrants from the FSM. I model the decision to move to the US as a function of the individual's human capital, skill level, family characteristics and employment experiences, conducting a probit analysis of the impact of these factors on moving to the US. The results indicate that individuals who leave the FSM are more likely to have above average education levels, to be single and to be younger than the typical male in the home country.

The second part of the paper examines the nature of self-selection on unobservable characteristics for immigrants to the US from the FSM. I employ the standard Heckman Selection correction technique to estimate a wage regression in the US for the new immigrants. The estimated inverse Mills' ratio provides an estimate of the nature of self-selection of the migrants to the US relative to non-migrants from the FSM. Based on the panel nature of my data, I have two types of exclusion restrictions which are improvements on previous research: household wealth measures in the home country and the impact of tropical typhoons on migration decisions. Second, I directly compare the home country wages of the migrant and non-migrant population in the FSM using nearest neighbor matching for those employed in the wage sector. After controlling for a number of observable characteristics, I find that there is a positive and significant difference, at the $10 \%$ level, in the observed home wages between migrants and nonmigrants. While the estimate is not highly statistically significant, perhaps due to the small sample size, this finding is in line with the results from the Heckman Selection procedure. The indication here is that “inherent ability” of the migrants are greater than non-migrants with similar observable characteristics; the movers are positively selected with respect to unobserved abilities.

Finally, I discuss the implications of this positive selection on the home country. Utilizing the 1997 Immigrant Survey and the 2000 Federated States of Micronesia Census, I trace the return flow of Micronesians to their home country in this three year time period. Remittances do not appear to be an important component of return flows to Micronesia. However, the return flow of migrants has been large, specifically with regard to highly educated migrants. Looking at the stock of high school and college 
educated individuals at home in the FSM and in the US, I find that the highly educated are more likely to return home than their less educated counterparts.

The paper is organized as follows: the next section provides a brief background history and overview of the Federated States of Micronesia and its unique relationship with the United States. Section III describes the creation of the panel data set and its characteristics. Section IV provides the empirical strategy and results for the immigrant self-selection on observable and unobservable characteristics. Section V explores the impact of this positive self-selection of immigrants on the home country via the remittances and return flow of human capital into the home country. Section VI concludes.

\section{Background History of the Federated States of Micronesia}

Few countries in the world have free entry into the United States; the Federated States of Micronesia is one of these countries. Any research involving international immigration to the US must account for the double selection that occurs - self-selection of individuals as well as screening by the destination country. Research on Micronesian immigrants eliminates the latter selection processes.

The Federated States of Micronesia (FSM) was formerly part of the Trust Territory of the Pacific governed by the US after the end of World War II. The FSM comprises over 600 islands spanning a thousand miles in the western Pacific Ocean. Today the FSM is an independent nation state with membership in the United Nations. Formerly, the FSM was part of the Trust Territory of the Pacific and had been listed on the United Nation's list of non-self governing territories. The Federated States of Micronesia was established in 1986 after a territory-wide vote overwhelmingly supported independence from the United States. The FSM today is governed by a US-style democracy with four states with a population of 100,000. Per capita GDP was estimated to be $\$ 1909$ in 1994, which puts the country in the lower middle income category of the World Bank rankings with other countries such as Algeria, Jamaica, Philippines and Swaziland. ${ }^{9}$

\footnotetext{
${ }^{9}$ See Heston, et. al. 2002 and http://www.boh.com/econ/pacific/fsmaer.asp.
} 
Once independence was established, the citizens of the FSM elected to continue their close relationship with the United States in a compact of free association. In exchange for allowing the US military to enter its ocean territories (an area of over one million square miles), the US agreed to provide governmental funding for the FSM over the course of 15 years. Additionally, FSM citizens were allowed free entry into the US at any time. Therefore, the FSM citizens have a unique advantage over citizens from other developing countries that face significant immigration hurdles into the US.

The FSM economy is typical of that of most developing countries. The public sector, which has traditionally been heavily financed by the US compact payments, is the largest component of the wage earning economy in the FSM. The private wage sector is smaller and primarily serves the government agencies and some small scale retail and consumer services.

By far the largest sector of the economy is the self-employed sector. Fully $50 \%$ of the adult male labor force is engaged in self-employment in either agriculture or fishing or a combination of the two. The wage sector represents only $41 \%$ of the adult male labor force, while individuals engaged in both self-employment in agriculture and the wage sector account for the other $9 \%$ of the adult male labor force population.

\section{Data Set Creation and Characteristics}

The data for this research come from the 1994 FSM Census of Population and Housing and the 1997 Micronesian Immigrant survey conducted in Hawaii, Guam and Saipan. ${ }^{10}$ The censuses are a complete enumeration of the entire population of the FSM and provide standard information on education, age, birth, income, family statistics and housing characteristics. The enumeration was conducted by the FSM Statistics Office with assistance from the US Census Bureau International Programs Division and the US Department of the Interior Office of Insular Areas.

\footnotetext{
${ }^{10}$ Hawaii is the $50^{\text {th }}$ state of the U.S., Guam is a territory of the U.S., and Saipan is part of the Commonwealth of U.S. As the number of immigrants to Saipan is relatively small (less than 70) and the island is located very close to Guam, for the remainder of this paper, the Saipan immigrants shall be included with the Guam immigrant pool.
} 
The immigrant surveys were conducted utilizing the snowball methodology in the three major immigrant receiving areas for FSM residents. The purpose of the surveys was to assess the impact of the FSM immigrants on the receiving communities. Based on the 2000 US and Guam Public Use Micro Samples appropriately adjusted back to 1997 , approximately $86 \%$ of the immigrant population from the FSM was surveyed. The remaining 14\% of FSM immigrants residing in the US are located primarily in California and no survey data exist for them. However, according to the 2000 Census, they are well educated; therefore, the selection resulting from omitting the $14 \%$ of immigrants in the continental US probably does not drive the findings in this research. ${ }^{11}$ The data contained in the immigrant surveys were similar to those found in the FSM Census. The enumeration was conducted by the US Census Bureau International Programs Division and the US Department of the Interior Office of Insular Areas.

I secured use of both of these data sets after traveling to the Federated States of Micronesia in the fall of 2003. No names were provided with the data. Therefore, it was necessary to match the individual records between the census and the immigrant surveys based on time-invariant characteristics available in the data. Individuals in the 1997 Micronesian Immigrant Survey who indicated that they left the FSM after 1994 were selected for this research as these individuals were certain to have been included in the 1994 census enumeration. Records were merged according to day, month and year of birth, sex, place of birth and duplicate matches were eliminated using educational attainment to distinguish between true and false matches. ${ }^{12}$ A full description of the matching procedure, variables and successes as well as robustness checks on the matching methodology is provided in the appendix.

A total of 557 out of 658 matches were made in this data for adult males. This represents $84 \%$ of the total possible immigrants who left the FSM within the time period 1995-1997. I restricted these

\footnotetext{
${ }^{11}$ According to the 2000 1\% PUMS, the majority of FSM adults in the continental US are high school educated and some college educated; this puts them above the FSM average of 10 years of education and the high school educated average of the Guam and Hawaii immigrant groups. Therefore, this missing group of $14 \%$ would most likely increase the findings of positive selection of immigrants to the US.

${ }^{12}$ In the final dataset, I restrict the sample to adult males 18 years and older; as a further robustness check to this matching methodology, I exclude males less than 25 years of age and the results remain qualitatively similar. Additionally, it was possible to exclude males who report education as their primary reason for migration to the US (most of the educational migrants are already excluded from this analysis as they report being out of the labor force completely) and I find little difference from my original matching methodology. Adding marital status as a further distinguishing variable provided both qualitatively and quantitatively similar results.
} 
matches to two subgroups: group one - all males, ages 18-65 and group two - all males, ages 18-65 who were in the labor force in $1994 .{ }^{13}$ The data also allows me to focus only on the individuals who report being in the labor force in 1997; this excludes the individuals who are currently attending college or other educational institutions in Hawaii and Guam. By focusing on only the economic immigrants to the US, my results provide clearer evidence for the true nature of immigrant self-selection; education-seeking migrants may confound efforts to uncover self-selection given their differing motivations for moving from economic migrants. This restriction of the data results in a total of 430 migrants, with 20,651 nonmigrants in the FSM, for a migration rate (over three years) of $2.1 \%$ for the total FSM adult male population. These 430 migrants report being in the labor force in Hawaii or Guam but they were not necessarily in the labor force back home in the FSM. The second subset restricts the data to individual immigrants who were both in the labor force in 1997 in the US as well as in the labor force in 1994 in the FSM. No previous research has been able to restrict the data in this way. For this subset of the population there are 305 migrants and 16,452 non-migrants in the FSM. While there are approximately 100,000 people in the Federated States of Micronesia, this research focuses on the adult male population in the labor force. ${ }^{14}$ The Federated States of Micronesia is typical of most developing countries in that it has a population pyramid which is heavily weighted at the bottom. In fact, half of the population is below the age of eighteen.

Tables $1 \mathrm{a}$ and $1 \mathrm{~b}$ provide the means of the migrant and non-migrant adult males (18-65) for the total adult and labor force populations respectively. It is important to note that this analysis examines the incentives to migrate for the total male labor force population of a developing country. Previous research restricted analysis to only those individuals who were employed in the wage sector; here, I look at the complete picture by including the self-employed in agriculture.

\footnotetext{
${ }^{13}$ The total adult male labor force includes men who were in the wage sector, self-employed, or unemployed; the excluded category here is out of the labor force completely. Additionally, men who reported working in the household compound were included as self-employed in agriculture. Men's work in the household compound means agricultural work or animal husbandry.

${ }^{14}$ While females do migrate, they are a relatively small proportion of the labor force in the FSM and are excluded from this analysis. Additionally, it appears that a large proportion of the females that migrate are doing so for educational purposes.
} 
Due to the fact that I have included the self-employed in agriculture, wage sector employed and the individuals out of the labor force, I do not include wage or salary income in 1994 for the regressions that follow. ${ }^{15}$ The census data does contain wages for individuals who are employed in the wage sector but, unfortunately, no useable measure exists in the census data for annual income for the self-employed in agriculture. Nor is it possible to estimate a shadow wage for the self-employed in agriculture as there is no information on either the output or inputs to agricultural production contained in the census data.

Immigrants to the US from the FSM are on average about 8 years younger than the average male who remains in the home country. This finding is consistent with the human capital theory of immigration, where the decision to migrate is considered an investment and younger individuals have higher payoffs to migration and undertake it more frequently.

The years of education variable shows that the migrant population is slightly more educated than the non-migrant population, but this difference is not statistically significant at conventional levels. The education dummy variables hint at the finding that the migrants will be positively selected on their observable characteristics relative to the non-migrant group. At the low end of the education dummy variables, we see that the migrant pool is less likely to be represented. In the middle education categories, the migrant pool is overly represented as compared to the non-migrant pool. The average years of education in the FSM for adult males is 10 years, therefore, over representation in the Nine to Twelve Years and High School Diploma education dummies shows that the migrants are positively selected (above average) on observable characteristics. The difference between the High School Diploma for the migrant and non-migrant group is statistically significant at the $10 \%$ level.

The Some College Plus educational dummy variable shows migrants are less likely to be drawn from the highest educational category. At first glance this would seem to indicate that migrants can not be positively self-selecting on observed characteristics. However, in the FSM, it is not possible to receive a Bachelor's Degree as there are no four-year universities. Therefore, this category more accurately

\footnotetext{
${ }^{15}$ Including a dummy variable indicating whether an individual receives wage income does not change the nature of self-selection with respect to observable characteristics.
} 
reflects the few migrants who have attended the single junior college in the FSM in relation to the large amount of college-educated return migrants from Hawaii and Guam, which will be discussed in Section V.

The migrant group is also statistically significantly less likely to be married than their nonmigrant counterparts in the FSM. The state of residence dummy variables indicates the migrants' tendency to be drawn more than proportionately from a single state, Chuuk. The state of Chuuk has the highest population and has a long history of sending residents abroad, so this finding is in keeping with the literature stressing the importance of networks in formulating immigration decisions.

Finally, two of the three typhoon dummy variables show that migrants were less likely to have come from areas that were struck by typhoons than residents of other FSM regions not affected by typhoons in the previous five years. This finding will drive my first stage results in the Heckman Selection Correction to be discussed below.

\section{Empirical Strategy for Detecting the Self-Selection of Immigrants}

\section{A. Immigrant Self-Selection on Observable Characteristics - Probit Regression Analysis and Results}

The first step in analyzing the self-selection of immigrants to the US is to identify the role of immigrants’ observable characteristics. The empirical strategy for estimating the determinants of migration to the US from the FSM is the estimation of a reduced form probit regression.

$$
\operatorname{Pr}[\text { Migration }=1]_{i}=\alpha_{i}+X_{i} \beta+Y_{i} \delta+\varepsilon_{i}
$$

In the equation above, the probability of migration is a function of two variables: $\mathrm{X}$, which represents the individual's characteristics, and Y, which represents the familial characteristics for each individual as well as the assets of the individuals and their households. I assigned the dependent variable according to whether or not an individual migrated to the US; for practical purposes this means that an individual appears in both the 1994 FSM Census and the 1997 Micronesian Immigrant survey. This estimation differs from other attempts in that both the $\mathrm{X}$ and $\mathrm{Y}$ variables are known for individuals while they are at 
home, that is, in the FSM in 1994. Typically, data on immigrants only contains information about individuals in the destination country.

Table 2 provides the results from the reduced form probit estimation detailed in the previous section for the two different groups of adult males in the FSM. The two groups examined in the table are: the total adult male population 18-65 and the total 18-65 male labor force (including the self-employed in agriculture). The education dummy variables provide information on the selection on observable characteristics. The omitted education category is zero years of schooling which is not a trivial number in this developing country. Tables $1 \mathrm{a}$ and $1 \mathrm{~b}$ indicate that approximately $8-9 \%$ of this group has no formal education. The two specifications for the labor force group show that the high school diploma dummy is statistically significant at the $5 \%$ significance level. In the FSM, the average education level for adult males is 10 years, therefore the positive sign and statistical significance of this education dummy indicates that there is positive selection on observable characteristics. The point estimates are positive and indicate that having a high school diploma increases an individual's probability of migration by $50.8 \%$. The difference between the two specifications is the inclusion of receipt of domestic remittances, the log of household income, household asset and typhoon dummies. These probit regressions will serve as the first stage of the Heckman Selection correction procedure conducted in the next section.

Age is also a significant determinant of migration to the US. Both the age and age squared variables are statistically significant; the negative and positive sign for the level and squared forms of the variable indicate that the young are more likely to migrate. This result conforms to the human capital theory of immigration. Holding all other observable characteristics constant, a younger individual is more likely to migrate than an older individual; this is due to the fact that the present value of gains to migration are larger for individuals who have a greater number of periods remaining in their labor force life spans. These results mirror those found in the table of means, which showed a statistically significant difference in age between the migrant and non-migrant groups.

Marital status does appear to be a statistically significant determinant of migration. The coefficient estimate is negative, as we would suspect, but it reaches statistical significance at the $10 \%$ 
level. In addition, other variables were included in these regressions such as the total household income and whether the family receives remittances from a domestic source. ${ }^{16}$ The log of household total income appears to discourage migration, but again this estimated coefficient is not statistically significant. A domestic source of remittances also appears to reduce the propensity for an individual to migrate, but the coefficient is not statistically significant at conventional levels. Both of these variables indicate that households with a sufficient level of income were less likely to send a household member abroad.

In the second grouping in this table, the entire adult male population (including men both in and out of the labor force as reported in the 1994 FSM census) is presented. We see that generally the results look very similar to those of the previous two columns. Importantly, we see that the positive selection on education still holds in this case. The magnitudes and statistical significance do not change in any meaningful way between the total labor force columns and the total adult male population columns. Once again, these probit regressions will be used as the first stage for the Heckman Selection correction procedure to follow. The coefficient on receipt of domestic remittances is now statistically significant at the $5 \%$ level, indicating that households with a domestic flow of remittances are less likely to send a household member abroad. Generally, the results found here indicate that the immigrants are drawn from the upper end of the observable skill distribution.

\section{B. Immigrant Self-Selection on Unobservable Characteristics}

The previous section described the direction of immigration self-selection on observable characteristics. The evidence presented indicates that there is positive selection on the observable characteristics of immigrants to the US from the FSM when using the complete labor force population (both wage and self-employed sectors). Individuals with above average education (high school graduates and some college education) are more likely to migrate to the US than the average FSM adult male. This next section is concerned with uncovering the self-selection on unobservable characteristics. Due to the

\footnotetext{
${ }^{16}$ Remittances from foreign source were not statistically significant at conventional levels in any of these specifications and was not reported here.
} 
unique panel nature of this data, two attempts can be undertaken to determine the direction of selection on unobservable characteristics.

First, I conduct nearest neighbor matching to determine the nature of selection. This method compares the home country wages of the migrant and non-migrant groups matched on a number of characteristics prior to emigration. Second, I employ the standard method (Heckman Selection Correction) of estimating the selection on unobservable characteristics. The Heckman Selection uses data on the wages of the FSM migrants at the destination and demographic characteristics of the non-migrants in the home country (FSM) to estimate the self-selection on unobservable characteristics. It is important to note that the nearest neighbor matching and Heckman Selection correction techniques use completely different outcome variables - the first uses wages at home in 1994, while the second uses wages abroad in 1997 - yet both techniques provide the same results: positive selection on unobservable characteristics.

\section{i. Nearest Neighbor Matching Methodology and Results}

Determining the selection on unobservable skill characteristics can be achieved with the estimation of a nearest neighbor match for the two groups, migrants and non-migrants, at home in the FSM in 1994. This method provides the clearest, most direct method of estimating the direction of selfselection on unobservable characteristics. No other research has been able to estimate self-selection of an entire country flow directly; the panel nature of my data is unique in the immigration literature. I have matched the two groups along the following categories: age, age squared, education, education squared, wage sector employment, marital status dummy, state level dummy variables, total household income variables and interaction terms. Once individuals from the migrant group have been matched with a counterpart in the non-migrant group a simple difference is calculated between their 1994 home wages in the FSM. This is the most direct test possible on self-selection. The residual differences between similarly matched individuals must be attributed to unobserved qualities or abilities that are compensated for by the labor market.

The estimated residual of log income between the two groups was positive and statistically significant at the $10 \%$ level are reported in Table 3 . The outcome of this matching procedure shows that 
although I have controlled for the observable determinants of wages, a sizeable and statistically significant difference in log income between these two groups still exists. These unobservable characteristics are presumably the ability or skills that are unmeasured in these data sets. Table 3 indicates that only 154 of the migrants report wages or business earnings in 1994. Therefore, I can only discuss the nature of self-selection for the migrants that are drawn from the wage sector and those selfemployed small business owners. The matched counterparts to these 154 emigrants are found in the pool of non-migrants in the FSM. The results indicate that prior to migration, the migrants were earning on average \$713 more annually than an identical (based on observed characteristics) non-migrant. The difference in earnings can be attributed to the unobserved heterogeneity such as ability or skills.

\section{ii. Heckman Selection Correction Procedure and Results}

In this section I employ the standard method used for detecting the self-selection of immigrants. ${ }^{17}$ While the nearest neighbor matching procedure is a direct test of self-selection, the Heckman Selection Correction relies on several assumptions about the data. ${ }^{18}$ I first estimate the probability that individuals would be selected into the sample (that is, emigrate to the US). Second, I estimate a wage regression for FSM migrants in the US and include the inverse Mills ratio estimated from the previous regression to control for the selection into the sample. As an exogenous determinant of migration out of the FSM, I use three dummies for whether a typhoon (typhoons Axel, Owen, or Yuri) had struck the potential migrants’ islands in the previous five years and caused significant damage to be declared a US Federal disaster area (and hence eligible for the exogenous US disaster-relief funding) by the US Federal Emergency Management Agency (FEMA). ${ }^{19}$ I contend that these three typhoon dummy variables are exogenous to

\footnotetext{
${ }^{17}$ See Robinson and Tomes (1982), Ramos(1991), Tunali (2000), or Brucker (2004).

${ }^{18}$ The most serious assumption is that the error terms are distributed normally; a logistic regression is required to estimate the first stage of sample selection - this functional form assumption may not be accurate in many situations. An additional requirement is that there exists some exogenous determinant of immigration that is not correlated with a wage equation. These requirements are not negligible.

${ }^{19}$ Over the course of three years in the early 1990's, there were three typhoons that hit different parts of the FSM. I created three dummy variables for whether or not these storms hit and caused damage in a particular region. I used Federal Emergency Management Agency (FEMA) data on typhoons in the Pacific. The FSM is eligible for US FEMA funds in the event of destructive storms under the Compact of Free Association with the United States. Therefore, when the storms occur and cause significant damage there is an influx of US funds for construction and rebuilding efforts. This may directly lower the propensity for individuals from affected areas to leave as
} 
the wage determination outside of the FSM. ${ }^{20}$ As a second exogenous determinant of migration, I use measures of household assets which I contend are not directly correlated with the ability of the individual migrant. $^{21}$

$$
\operatorname{Pr}[\text { Migration }=1]_{i}=\alpha_{i}+X_{i} \beta+Y_{i} \delta+Z_{i} \gamma+\varepsilon_{i}
$$

The exogenous determinant of immigration (self-selection) is represented by the vector $\mathrm{Z}$, which are the three typhoon dummy variables described previously and the household wealth measures. Once this has equation has been estimated, the Mills ratio is computed, which gives the inverse hazard ratio or the probability of being included in this sample. It is shown below:

$$
\text { Mill's Ratio }=\frac{\phi(x)}{1-\Phi(x)}
$$

In equation (14), $\phi$ represents the standard normal probability distribution function and $\Phi$ represents the standard normal cumulative distribution function. Then the Inverse Mill’s Ratio, $\lambda$, is included as a regressor in the OLS wage equation to correct for the sample selection.

$$
\ln (\text { wage })_{i}=\alpha_{i}+\beta X_{i}+\eta \lambda_{i}+\varepsilon_{i}
$$

construction jobs become plentiful. Alternatively, the very visible nature of the storms may increase the amount and/or frequency of remittances sent back to individuals in these affected areas which thereby reduces their incentives to immigrate to the US.

${ }^{20}$ These particular typhoons should have little or no impact on wages outside of the FSM; only one of these typhoons hit both the FSM and one of the destinations, Guam. Additionally, one may be concerned that certain areas of the FSM are prone to destruction by typhoons given their location. There were only three other typhoons that affected the FSM in the ten year time period 1984-1994. Two of these typhoons hit the western islands of Chuuk atoll and Ulithi atoll, the third affected the eastern islands of Nukuoro atoll and Pohnpei island. Of the three typhoons that I use for my identification strategy, two affect the eastern islands, while one affects primarily the western islands. These previous typhoons occur in different places than the three more recent typhoons. In all, none of the islands seems particularly predisposed or immune to the effects of western Pacific typhoons.

${ }^{21}$ One of the potential determinants of emigration is the household wealth. Theoretically, an abundance of household assets or wealth could facilitate emigration abroad where there are significant costs to emigration. On the other hand, high household wealth may indicate that there is less of an incentive to emigrate abroad as the household has enough resources at hand. One issue with the use of assets, however is that it may be endogenous in the probability of emigration equation. However, the measures I have are assets at a household level. Therefore, the assets are not a direct function of a particular individual's ability but the cumulative ability and earnings of all household members. For married men, the correlation of ability and asset accumulation is even less of a problem. In three of the four states of the FSM the custom is for the husband to relocate to his wife's family compound, they are matrilineal and matrilocal. 
In this case, the variable $\lambda$ represents the inverse Mill's ratio and the estimated coefficient $\eta$ gives us an estimate of how unobservable characteristics affect the wages of the new immigrants to the US. The estimated coefficient on Mill's ratio indicates the nature of selection on unobservable skill characteristics.

In Table 4, the Heckman Selection correction is conducted on the total adult male 18-65 population. Utilizing the standard Heckman correction with individual data on wages and employment at the destination country, I have found that selection is positive with respect to the unobservable characteristics. The first stage probit regression utilizes the same data and specifications as described in an earlier section and in Table 2.

The first specification presented in table 4 is the total adult male population and uses only the typhoon variables as exogenous determinants of migration. These three variables are jointly significant at the $1 \%$ level. Importantly, we see the coefficient on the inverse Mill's ratio is positive and statistically significant. The positive coefficient indicates that the FSM migrants are above average in their unobservable characteristics with regard to the non-migrants in the FSM.

The second specification in Table 4 includes the additional measures of household asset dummies, log of household incomes and domestic remittance dummy variables. Once again, we see that these instruments are strong (significant at the 1\% level). The coefficient on the Mills ratio is also statistically significant and positive in sign. The comparison here includes all adults males, regardless of labor force status, in the FSM. Previous research tended to arbitrarily truncate the data to include only the wage sector employed.

Table 5 presents a similar analysis for the adult male labor force group. In both specifications presented, the coefficient on the inverse Mill's ratio is positive and statistically significant at the $5 \%$ level. The joint significance of the instruments used to determine migration is statistically significant at the 5\% level for the more parsimonious specification which uses only the typhoon variables. The second specification with the additional household-level variables is only significant at the $20 \%$ level. In contrast to the analysis presented in Table 4, this comparison examines only those individuals who were employed in the labor force in the home country. I include the self-employed which is typically excluded 
due to data limitations in most immigration research; however, this is not a trivial omission for a developing country where a large proportion of the labor force may be employed primarily in the nonwage sector.

It is clear in the results presented that there is no evidence for negative selection on unobservable characteristics for the immigrants from the FSM. Whether using the occurrence of typhoons or the household assets, there is strong evidence for positive selection on unobservable characteristics here. These results contrast greatly with previous work that examined the nature of self-selection from Puerto Rico. In the Ramos study, the migrants were not compared with the appropriate reference group in the home. That work assumed those employed in the wage sector in the US were also employed in the wage sector in the home country.

\section{The Impact of Positive Self-Selection on the Home Country}

The self-selection of immigrants impacts both the sending and receiving countries. The impact of immigrants on destination countries has been studied extensively. ${ }^{22}$ As Borjas (1991) and others have shown, the changing composition of immigrant sending countries is responsible for the decline in immigrant skill levels over the $20^{\text {th }}$ century. Whether individuals come from the high or low end of the skill distribution is a second order concern when the source countries are low skilled in general.

Concerns about the nature of self-selection of immigrants have a potentially bigger impact on the sending countries. Large outflows of positively selected immigrants can result in a brain drain for the sending country decreasing the human capital and ability of the country to build and sustain effective institutions. On the other hand, a large outflow of low skilled individuals could decrease the inequality within a developing country. Remittances and the return flow of migrants are two ways in which the overall impact of positively selected initial outflows of migrants can be mitigated.

\footnotetext{
${ }^{22}$ See Card (1990) and Hunt (1992) for examples of analyses on the native work force given an exogenous and unexpected increase in the immigrant population in the US and France respectively.
} 


\section{A. Remittance Flows}

The total remittances sent in 1997 by all FSM migrants residing in the US are approximately \$560,000. The FSM GDP in 1997 was approximately \$231 million; total remittances account for less than one percent of the FSM GDP. For the recent cohort of immigrants, the total amount remitted is about $\$ 51,000$.

While we have already concluded that there is positive selection of immigrants from the FSM to the US, it appears that their above average skills and education do not translate into large remittances to the FSM. A potential explanation for the small size of total remittances is that the immigrant pool is relatively small and less than ten years old at the time of data collection. In any case, remittances do not appear to be a large resource for the FSM.

\section{B. Composition of Returnees}

A potentially larger resource is the return of highly skilled individuals to the FSM. It is generally very difficult to assess where individuals attained their education. However, there are no four-year degree granting institutions of higher learning in the FSM. Therefore, all of the college and graduate degrees in the FSM were received outside of the country. The existing stock of college graduates or higher degrees in the 2000 FSM census was 1054 people. In 1997, the outstanding stock of college graduates or higher degrees abroad was only 107 individuals. Some of these individuals in the 2000 FSM Census received their education prior to the complete elimination of immigration restrictions to the U.S. in 1986; these individuals received student visas and were educated in the US and returned home. While there may have been immigration restrictions that required these students to return home after completion of their education, there certainly are no restrictions in place today. Based on the 2000 FSM Census and the 1997 FSM Immigrant Survey, I conclude that, quite surprisingly, over $90 \%$ of the highly educated FSM residents choose to return to their home country and pass up more lucrative opportunities in the US.

These highly educated return migrants appear to contradict the predictions of the simple skill price model discussed earlier. The likely explanation is that the return migrants were never economic emigrants in the first place, they were educational migrants. All of these individuals earned their college 
or graduate degrees in a U.S. institution (in Guam, Hawaii or potentially even the continental US) and could have remained in those places. These individuals would also have been able to return to the US at any point in time, but choose not to leave. The average income for college educated persons in the FSM was \$12,000 in 2000. Comparably educated individuals in Hawaii, Guam and the continental U.S. would stand to make substantially more money. The return migration of the highly educated to the FSM potentially offsets the outflow of positively selected economic migrants.

This evidence underscores the importance of different categories of immigrants to the US when borders are fluid. Specifically, there may be family reunification immigrants, educational immigrants and economic immigrants, which was the focus of this paper. As I have discussed earlier, it is important to be able to categorize the type of immigrant in order to assess the impacts on both the home and destination countries. If we are to analyze the self-selection of immigrants, it is crucial to be able to distinguish between different kinds of immigrants. Without complete knowledge of the immigrants' motivations, previous work, education and wage experiences it is almost impossible to make meaningful comparisons between migrant populations in a destination country with the non-migrant population in the home country.

The results found here illustrate that migrant flows are also due to acquisition of human capital investments. Not all immigrants from developing countries are motivated solely by the differences in wages between home and destination countries. In this particular case, we see that although these individuals could earn more in the destination economies, they make a non-economic decision to return to their home country. Nationalism or perhaps family related issues may be driving this movement, but it would be difficult to conclude that economic forces are directly at play in this example. All of the return migrants face a substantial reduction in their wages earned.

\section{Conclusion}

Determining the nature of immigrant self-selection is confounded by immigration restrictions at the destination and a lack of data about the labor force characteristics of the immigrants in their home country. The Federated States of Micronesia is an excellent case study because of the high quality of the 
data and the lack of entry barriers to the United States. The data allow one to examine the true nature of self-selection at the individual level. This research has established that there is positive selection of migrants to the US with regard to both observable and unobservable characteristics.

Finally, I note some interesting facts with regard to the return flow of FSM citizens to their home country and discuss the impact of positive self-selection of economic migrants on the home country. While there does not appear to be a large amount of remittances flowing back into the FSM, there is a large influx of human capital. This is an intriguing result. These highly educated individuals could earn higher incomes abroad, they choose to return to the FSM for lower absolute wages. The economic migrants, on the other hand, do not appear to return home and do not send back a large amount of remittances.

This research raises interesting questions as to what actually drives return migration for different immigrant categories. As a development policy, will we see the return of highly skilled natives to developing countries as democracy spreads, business opportunities increase or rule of law is established? Or will education-only immigrants always return to their home country when borders are open? In the FSM, it appears that individuals are foregoing higher wages abroad for an opportunity to participate in their government and business development. Although there is an initial outflow of human capital with the economic emigrants, the return flow of educational emigrants is large and well educated. 


\section{Appendix I - Data Matching Methodology}

In creating this panel data set it was necessary to match individuals between the census and immigrant survey. As there were no explicit identifying variables such as names or social security numbers in the two data sets, I used other time-invariant identifying characteristics available in the two data sets.

I restricted the data to include only new immigrants to Hawaii and Guam that had arrived after the 1994 FSM Census; earlier immigrants to the US were excluded from this analysis. In this matching procedure, I included both males and females although for the analysis in the paper, I focus only on the adult male population which had higher wage sector employment probabilities. Additionally, I excluded individuals who did not indicate that they were in the US labor force; these individuals are most likely the educational migrants discussed earlier in the text. The variables that I based my matching efforts on were: sex, birth year, birth month, birth day, region and state of birth. Region of birth is a three digit code for the 76 municipalities located in the FSM; state of birth is a single digit code for the four states located in the FSM.

I matched the two data sets in four rounds. In the first round, individuals were exactly matched on sex, region of birth, day of birth, month of birth, year of birth. A total of 204 exact matches were found in this first round. The second round used the same variables above, except that state of birth was substituted for region of birth. I used the education variable to distinguish between true and false matches; duplicate matches that had large differences in education levels were eliminated. In this round, I found 499 matches. The third round proceeded by using sex, birth year, birth month and region of birth, duplicates were eliminated using the variable for day of birth. Relaxing the day constraint allowed for 138 additional matches. In the final matching round, I matched individuals on their sex, birth year, birth month and state of birth. To eliminate duplicates both education levels and the day of birth was used to distinguish between true and false matches. A total of 169 matches were found in this round.

Out of the possible 1036 immigrants in the 1997 immigrant survey of all adults ages 18-65, 1010 were successfully matched using this process, or a $97 \%$ match rate. The table below provides a summary 
of the matching procedure, number of matches at each round, and the variables used to distinguish between true and false duplicate matches.

\begin{tabular}{|l|c|l|}
\hline \multicolumn{3}{|c|}{ Matching Variables Used in Data Set Creation } \\
\hline \multicolumn{1}{|c|}{ Variables } & Matches & Duplicates Eliminated Using: \\
\hline Sex, Year, Month, Day, Region & 204 & \\
\hline Sex, Year, Month, Day, State & 499 & Education \\
\hline Sex, Year, Month, Region & 138 & Day \\
\hline Sex, Year, Month, State & 169 & Education, Day \\
\hline Total & 1010 & \\
\hline
\end{tabular}

I attempted several robustness checks on my matching procedure. In the first case, I excluded individuals who indicated that they had immigrated to the US for education reasons (a very small number as most were previously excluded when I removed the individuals who are out of the labor force). My results were exactly the same as those found when this group was included in the analysis. Second, I excluded males who were under 25 years of age as they have a higher likelihood of entering school in Hawaii or Guam than the older males. I found that the selection on observable characteristics remained positive and statistically significant even when the young males were excluded. Selection on unobservable characteristics also remained statistically significant at conventional levels. These results are presented in Appendix Tables I and II. Overall, the results seem to look similar to what I achieved with my original matching procedure. 


\section{References}

Abadie, A. et. al. "Implementing Matching Estimators for Average Treatment Effects in Stata.” The Stata Journal. Volume 4.3 (2004).

Abowd, J. and R. Freeman, eds. Immigration, Trade, and the Labor Market. (The University of Chicago Press: Chicago, Il.) 1991.

Arango, J., et al., “Theories of International Migration: a review and appraisal.” Population and Development Review, 19 (1993) p. 431-466.

Azam, J., “Those in Kayes: the impact of remittances on their recipients in Africa.” Working Paper, 2002.

Becker, S. and A. Ichino. "Estimation of Average Treatment Effects based on Propensity Scores.” Unpublished Manuscript.

Bhagwati, J. and Carlos Rodriguez, Eds. The Brain Drain and Taxation: Theory and Empirical Analysis. (North-Holland Co, Amsterdam)1976.

Bloom, D. and O. Stark, “The New Economics of Labor Migration.” The American Economic Review, 75(2), (1985) p. 173-178.

Borjas, George J., "Self-Selection and the Earnings of Immigrants.” American Economic Review 77(4), (1987) 531-553

Borjas, G. and R. Freeman, eds. Immigration and the Work Force. (University of Chicago Press: Chicago, Il.) 1992.

Borjas, G., “The economics of immigration.” Journal of Economic Literature, 32(4), (1994) p. 16671717.

Borjas, G., ed. Issues in the Economics of Immigration. (University of Chicago Press: Chicago, Il.) 2000.

Brucker, Herbert. “Do the Best Go West?” IZA Discussion Paper No. 986. 2004.

Card, D. “The Impact of the Mariel boatlift on the Miami labor market.” Industrial Labor Relations Review. Volume 40, 1990.

Cerrutti, M. and D. Massey, "On the auspices of female migration from Mexico to the United States.” Demography, 38(2), (2001) p. 187-200.

Chiquiar, D. and G. Hanson, "International migrations, self-selection and the Distribution of Wages: Evidence from Mexico and the United States.” Journal of Political Economy, v. 113, 2005.

Chiswick, Barry. “The Effect of Americanization on the Earnings of Foreign-born Men.” The Journal of Political Economy. Vol. 86, n. 5, (1978) p. 897-921.

Chiswick, B., “Are Immigrants Favorably Self-Selected? Migration Theory,” in Migration Theory: Talking Across Disciplines.Brettell, C. and J. Hollifield, eds. , (Routledge: New York, NY) 2000. 
Clark, X., T. Hatton, and J. Williamson, “Where do US immigrants come from, and why?” National Bureau of Economic Research, Working Paper 8998, (2002).

Cook, P. and C. Kirkpatrick, "Labor Market adjustment in small open economies: the case of Micronesia.” World Development, 26(5), (1998) p. 845-855.

Davis, B., D. Karemera, and V. Olguledo, “A gravity model analysis of international migration to North America,” Applied Economics, 32, (2000) p. 1745-1755.

Freeman, R., "Immigration from poor to wealthy countries: experience of the United States," European Economic Review, 37, (1993) p. 443-451.

Greenwood, Michael J. "Internal Migration and Developed Countries." Handbook of Population and Family Economics. Eds. M.R. Rosenzweig and O. Stark. Elsevier Science: 1997.

Grieco, E., The Remittance Behavior of Immigrant Households: Micronesians in Hawaii and Guam. (New York, NY: LFB Scholarly Publishing) 2003.

Goldin, C. "The Political Economy of Immigration Restriction in the United States, 1890 to 1921." in The Regulated Economy: A Historical Approach to Political Economy, C. Goldin and G.D. Libecap Eds., (Chicago: University of Chicago Press) 1994.

Hatton, T. and J. Williamson, "Demographic and economic pressure on emigration out of Africa," National Bureau of Economic Research, Working Paper 8124 (2001).

Hatton, T. and J. Williamson, "What fundamentals drive world migration?” National Bureau of Economic Research, Working Paper 9159 (2002).

Hatton, T. and J. Williamson, "International migration in the long-run: positive selection, negative selection and policy.” National Bureau of Economic Research, Working Paper 10529, (2004).

Heckman, J., “Shadow prices, market wages and labor supply,” Econometrica, 42(4), (1974) p. 679-694.

Heckman, J. and B. Honore, “The empirical content of the Roy model,” Econometrica, 58(5), (1990) p. 1121-1149.

Heston, Alan and Robert Summers and Bettina Aten, Penn World Table Version 6.1, Center for International Comparisons at the University of Pennsylvania (CICUP), October 2002.

Hunt, J. “The Impact of the 1962 repatriates from Algeria on the French labor market,” Industrial and Labor Relations Review. Volume 45, 1992.

Ichino, Andrea and Sasha Becker. "Stata programs for ATT estimation based on propensity score matching.” http://www.iue.it/Personal/Ichino, 2005.

International Organization for Migration. World Migration 2005: Costs and Benefits of International Migration. Volume 3, IOM World Migration Report Series, Geneva, Switzerland, 2005. 
Jacoby, H., "Shadow wages and peasant family labour supply: an econometric application to the Peruvian Sierra.” The Review of Economic Studies, 60(4), (1993) p. 903-921.

Jasso, Guillermina and Mark Rosenzweig. "Selection Criteria and the Skill Composition of Immigrants: A Comparative Analysis of Australian and US Employment Immigration.” Unpublished Manuscript, 2005.

Kapur, D. and J. McHale. Give Us Your Best and Brightest: The Global Hunt for Talent and Its Impact on the Developing World. (Center for Global Development: Washington, D.C.) 2005.

Katz, E. and O. Stark, “Labor Migration and risk aversion in less developed countries.” Journal of Labor Economics, 4(1), (1986) p. 134-149.

Lalonde, R. and R. Topel, "Economic Impact of International Migration and the Economic Performance of Migrants" in Handbook of Population and Family Economics, ed. M. Rosenzweig and O. Stark. Vol. 1b., (Elsevier Science: New York, NY) 1997.

Lucas, R., “Internal Migration in Developing Countries.” in Handbook of Population and Family Economics, ed. M. Rosenzweig and O. Stark. Vol. 1b. (Elsevier Science: New York, NY) 1997.

McKenzie, David, John Gibson and Steven Stillman, "How Important is Selection? Experimental vs. Non-Experimental Measures of the Income Gains from Migration” World Bank Policy Research Working Paper Number 3906, (2006)

Mincer, J., “Family migration decisions.” The Journal of Political Economy, 86(5), (1978) p. 749-773.

Munshi, K., "Networks in the modern economy: Mexican migrants in the US labor market.” Quarterly Journal of Economics, 118(2), (2003) p. 749-773.

Ramos, Fernando, A. “Out-Migration and Return Migration of Puerto Ricans.” in Immigration and the Work Force. (University of Chicago Press: Chicago, Il.) 1992, p. 49-66.

Razin, A. and E. Sadka, “International Migration and International Trade.” in Handbook of Population and Family Economics, ed. M. Rosenzweig and O. Stark. Vol. 1b. (Elsevier Science: New York, NY) 1997.

Robinson, C. and N. Tomes, "Self-Selection and interprovincial migration in Canada.” The Canadian Journal of Economics, 15(3), (1982) p. 474-502.

Rosenzweig, M., "Labor Markets in Low-Income Countries.” in Handbook of Development Economics, ed. H. Chenery and T. Srinivasan. Vol. 1. (Elsevier Science Publishers: New York, NY) 1988.

Roy, A.D., "Some thoughts on the distribution of earnings." Oxford Economic Papers, 3(2), (1951) p. 135-146.

Saks, Raven and Abigail Wozniak, "Labor Reallocation over the Business Cycle: New Evidence from Internal Migration.” Finance and Economics Discussion Series, Federal Reserve Bank, Washington, D.C., 2007 - 32.

Sjaastad, L., “The cost and returns of human migration.” The Journal of Political Economy, 70(5), (1962) p. 80-93. 
Stark, O., J. Taylor, and S. Yitzhaki, "Migration, remittances and inequality: a sensitivity analysis using the extended gini index.” Journal of Development Economics, 28, (1988) p. 309-322.

Stark, O., The Migration of Labor. (Cambridge, MA: Basil Blackwell, Inc.) 1991.

Tunali, Insan. “Rationality of Migration.” International Economic Review, 41, 2000.

Williamson, J., “Migration and Urbanization” in Handbook of Development Economics, ed. H. Chenery and T. Srinivasan. Vol. 1. (Elsevier Science Publishers: New York, NY) 1988. 
Variable

Age

Age Squared

Years of Education

Zero Education Dummy

One to Six Years Education Dummy

Seven to Eight Years Education Dummy

Nine to Twelve Years Education Dummy

High School Diploma Dummy

Some College Plus Dummy

Domestic Remittances Dummy

Married Dummy

Wage Sector Dummy

Yap State Dummy

Chuuk State Dummy

Pohnpei State Dummy

Kosrae State Dummy

Typhoon Yuri Dummy

Typhoon Axel Dummy

Typoon Owen Dummy

Log Wages in US

\begin{tabular}{|r|r|r|}
\hline \multicolumn{3}{|c|}{ Non-Immigrants } \\
\hline Obs & Mean & Std. Dev. \\
\hline 20651 & 34.35 & 12.16 \\
20651 & 1327.88 & 935.07 \\
20651 & 10.20 & 4.62 \\
20651 & 0.09 & 0.28 \\
20651 & 0.10 & 0.30 \\
20651 & 0.17 & 0.38 \\
20651 & 0.22 & 0.41 \\
20651 & 0.18 & 0.38 \\
20651 & 0.25 & 0.43 \\
20651 & 0.13 & 0.34 \\
20651 & 0.64 & 0.48 \\
20651 & 0.43 & 0.49 \\
20651 & 0.11 & 0.32 \\
20651 & 0.47 & 0.50 \\
20651 & 0.35 & 0.48 \\
20651 & 0.07 & 0.26 \\
20651 & 0.35 & 0.48 \\
20651 & 0.42 & 0.49 \\
20651 & 0.04 & 0.20 \\
0 & & \\
\hline
\end{tabular}

\begin{tabular}{|c|}
\hline T-test \\
\hline-24.07 \\
-26.10 \\
1.11 \\
-1.43 \\
-3.66 \\
0.09 \\
2.69 \\
1.74 \\
-1.80 \\
-0.97 \\
-11.33 \\
-7.13 \\
-1.06 \\
4.62 \\
-3.17 \\
-2.64 \\
-3.17 \\
-4.20 \\
0.88 \\
\end{tabular}




\begin{tabular}{|l|}
\hline Variable \\
\hline Age \\
Age Squared \\
Years of Education \\
Zero Education Dummy \\
One to Six Years Education Dummy \\
Seven to Eight Years Education Dummy \\
Nine to Twelve Years Education Dummy \\
High School Diploma Dummy \\
Some College Plus Dummy \\
Domestic Remittances Dummy \\
Married Dummy \\
Wage Sector Dummy \\
Yap State Dummy \\
Chuuk State Dummy \\
Pohnpei State Dummy \\
Kosrae State Dummy \\
Typhoon Yuri Dummy \\
Typhoon Axel Dummy \\
Typoon Owen Dummy \\
Log Wages in US
\end{tabular}

\begin{tabular}{|r|r|r|}
\hline \multicolumn{3}{|c|}{ Non-Immigrants } \\
\hline Obs & Mean & Std. Dev. \\
\hline 16452 & 35.45 & 11.41 \\
16452 & 1386.98 & 880.17 \\
16452 & 10.31 & 4.65 \\
16452 & 0.08 & 0.27 \\
16452 & 0.10 & 0.30 \\
16452 & 0.18 & 0.38 \\
16452 & 0.20 & 0.40 \\
16452 & 0.18 & 0.39 \\
16452 & 0.26 & 0.44 \\
16452 & 0.12 & 0.32 \\
16452 & 0.71 & 0.45 \\
16452 & 0.54 & 0.50 \\
16452 & 0.12 & 0.32 \\
16452 & 0.46 & 0.50 \\
16452 & 0.36 & 0.48 \\
16452 & 0.07 & 0.25 \\
16452 & 0.36 & 0.48 \\
16452 & 0.43 & 0.49 \\
16452 & 0.04 & 0.20 \\
0 & & \\
\hline
\end{tabular}

\begin{tabular}{|r|r|r|}
\hline \multicolumn{3}{|c|}{ Immigrants } \\
\hline \multicolumn{1}{|c|}{ Obs } & Mean & Std. Dev. \\
\hline 305 & 26.75 & 7.49 \\
305 & 771.64 & 486.25 \\
305 & 10.51 & 3.94 \\
305 & 0.06 & 0.24 \\
305 & 0.05 & 0.22 \\
305 & 0.20 & 0.40 \\
305 & 0.25 & 0.43 \\
305 & 0.23 & 0.42 \\
305 & 0.22 & 0.41 \\
305 & 0.11 & 0.31 \\
305 & 0.47 & 0.50 \\
305 & 0.38 & 0.49 \\
305 & 0.10 & 0.30 \\
305 & 0.56 & 0.50 \\
305 & 0.30 & 0.46 \\
305 & 0.04 & 0.19 \\
305 & 0.30 & 0.46 \\
305 & 0.34 & 0.47 \\
305 & 0.05 & 0.21 \\
305 & 9.37 & 0.38 \\
\hline
\end{tabular}

\begin{tabular}{|c|}
\hline T-test \\
\hline-19.86 \\
-21.46 \\
0.88 \\
-1.61 \\
-3.45 \\
0.86 \\
1.83 \\
1.74 \\
-1.69 \\
-0.48 \\
-8.24 \\
-5.42 \\
-0.94 \\
3.53 \\
-1.95 \\
-3.04 \\
-1.95 \\
-3.10 \\
0.35 \\
\hline
\end{tabular}


Males 18-65 in Labor Force

\begin{tabular}{|c|c|c|c|c|}
\hline & 1 & 2 & 3 & 4 \\
\hline \multirow[t]{2}{*}{ 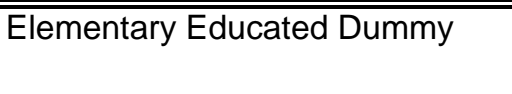 } & -0.055 & -0.049 & 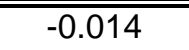 & -0.007 \\
\hline & [0.124] & [0.124] & [0.103] & [0.103] \\
\hline \multirow[t]{2}{*}{ Middle School Educated Dummy } & 0.076 & 0.073 & 0.055 & 0.053 \\
\hline & [0.100] & [0.100] & [0.084] & [0.084] \\
\hline \multirow[t]{2}{*}{ High School Educated Dummy } & 0.084 & 0.081 & 0.053 & 0.055 \\
\hline & [0.098] & [0.098] & [0.080] & [0.080] \\
\hline \multirow[t]{2}{*}{ High School Diploma Dummy } & $0.202^{\star \star}$ & $0.201^{\star \star}$ & $0.187^{\star \star}$ & $0.198^{\star \star}$ \\
\hline & [0.099] & [0.101] & [0.083] & [0.084] \\
\hline \multirow[t]{2}{*}{ Some College Plus Dummy } & $0.196^{\star \star}$ & $0.200^{*}$ & $0.155^{*}$ & $0.172^{\star \star}$ \\
\hline & {$[0.100]$} & [0.103] & [0.082] & [0.084] \\
\hline \multirow[t]{2}{*}{ Age } & $-0.051^{\star \star \star}$ & $-0.051^{\star \star \star}$ & $-0.042^{\star \star \star}$ & $-0.043^{\star \star \star}$ \\
\hline & {$[0.015]$} & [0.015] & {$[0.013]$} & {$[0.013]$} \\
\hline \multirow[t]{2}{*}{ Age Squared } & 0.000 & 0.000 & 0.000 & 0.000 \\
\hline & [0.000234] & [0.000234] & {$[0.000205]$} & [0.000204] \\
\hline \multirow[t]{8}{*}{ Married Dummy } & $-0.101^{\star}$ & $-0.098^{\star}$ & $-0.107^{\star *}$ & $-0.105^{\star \star}$ \\
\hline & [0.053] & [0.053] & {$[0.047]$} & {$[0.047]$} \\
\hline & 0.013 & 0.022 & -0.031 & -0.030 \\
\hline & [0.111] & [0.111] & [0.093] & [0.094] \\
\hline & $-0.196^{\star}$ & $-0.191^{*}$ & -0.200 ** & $-0.189 * \star$ \\
\hline & [0.106] & [0.109] & [0.089] & [0.093] \\
\hline & -0.154 & -0.134 & -0.125 & -0.143 \\
\hline & {$[0.117]$} & [0.120] & [0.096] & {$[0.100]$} \\
\hline \multirow[t]{2}{*}{ Domestic Remittances Dummy } & & -0.103 & & $-0.121^{\star \star}$ \\
\hline & & [0.073] & & {$[0.060]$} \\
\hline \multirow{2}{*}{ Log HH Total Income } & & -0.006 & & -0.006 \\
\hline & & [0.007] & & [0.005] \\
\hline Asset Dummies & N & Y & N & Y \\
\hline Constant & Y & Y & Y & Y \\
\hline Observations & 16821 & 16821 & 21172 & 21172 \\
\hline Pseudo R squared & 0.073 & 0.076 & 0.075 & 0.077 \\
\hline Wald Chi-Square (d.f) & $212.75(11)$ & $232.56(20)$ & $277.46(11)$ & $298.79(20)$ \\
\hline
\end{tabular}

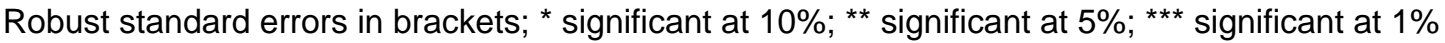
Asset Dummies: rooms in house, number of automobiles, number of boats, freezer dummy, radio dummy, airconditioner dummy, home ownership dummy 
Table 3: Nearest Neighbor Matching for Individuals in FSM

\begin{tabular}{|c|c|c|c|c|}
\hline Number of Emigrants & Controls & Estimated Difference & Standard Error & T Statistic \\
\hline $\begin{array}{c}154 \\
(\text { Mean }=7.92, \text { SD }=1.16)\end{array}$ & $\begin{array}{c}143 \\
(\text { Mean }=7.62, \text { SD }=1.44)\end{array}$ & 0.299 & 0.158 & 1.892 \\
\hline
\end{tabular}

Outcome Variable is log wages and farm income in FSM in 1994

Matched on: age, age squared, education, education squared, marital dummy, wage sector dummy, log household income,

boat ownership, and state of residence dummies.

stata code from Ichino et. al. 
Table 4: Heckman Correction using Panel Data

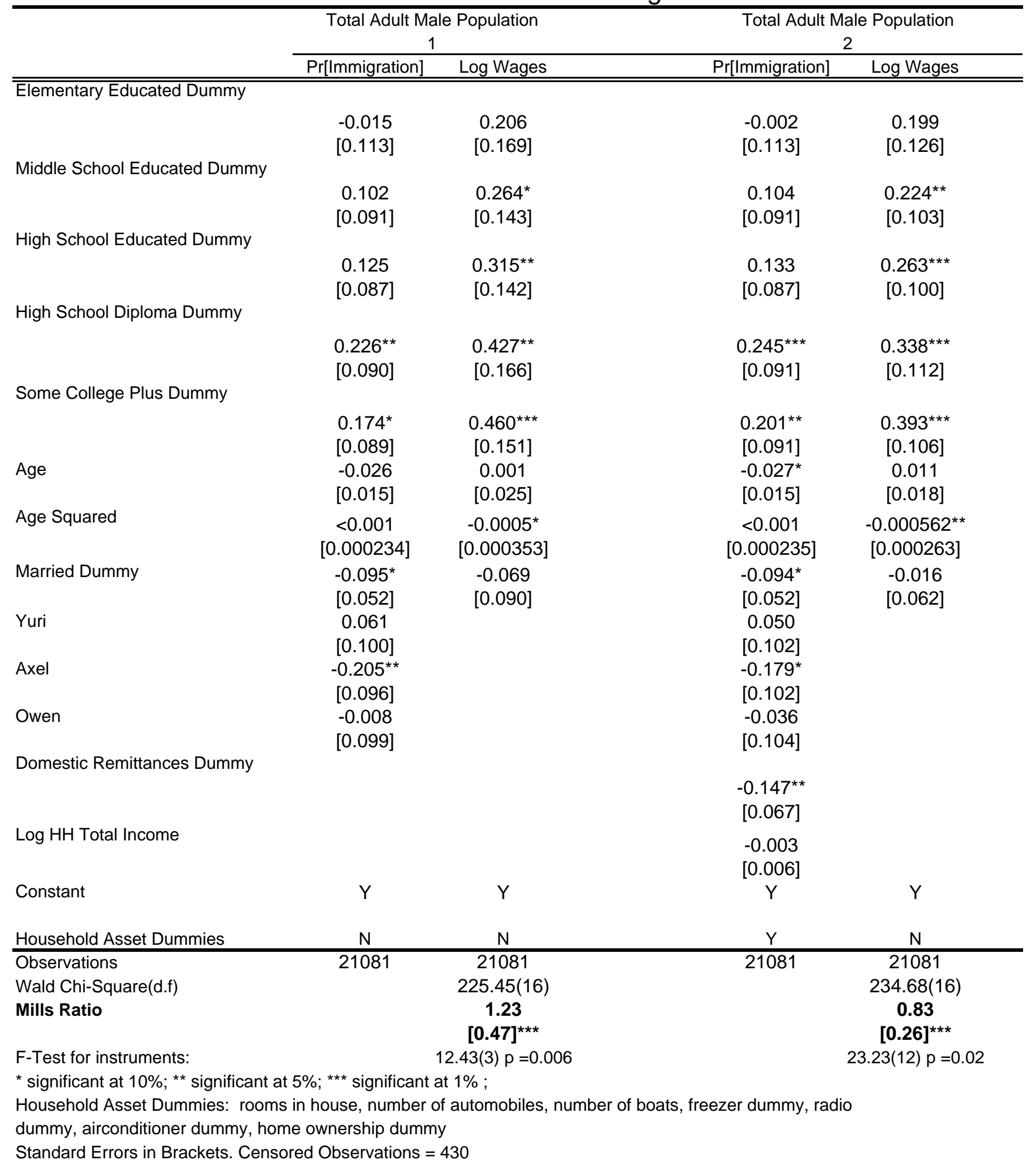


Table 5: Heckman Correction using Panel Data

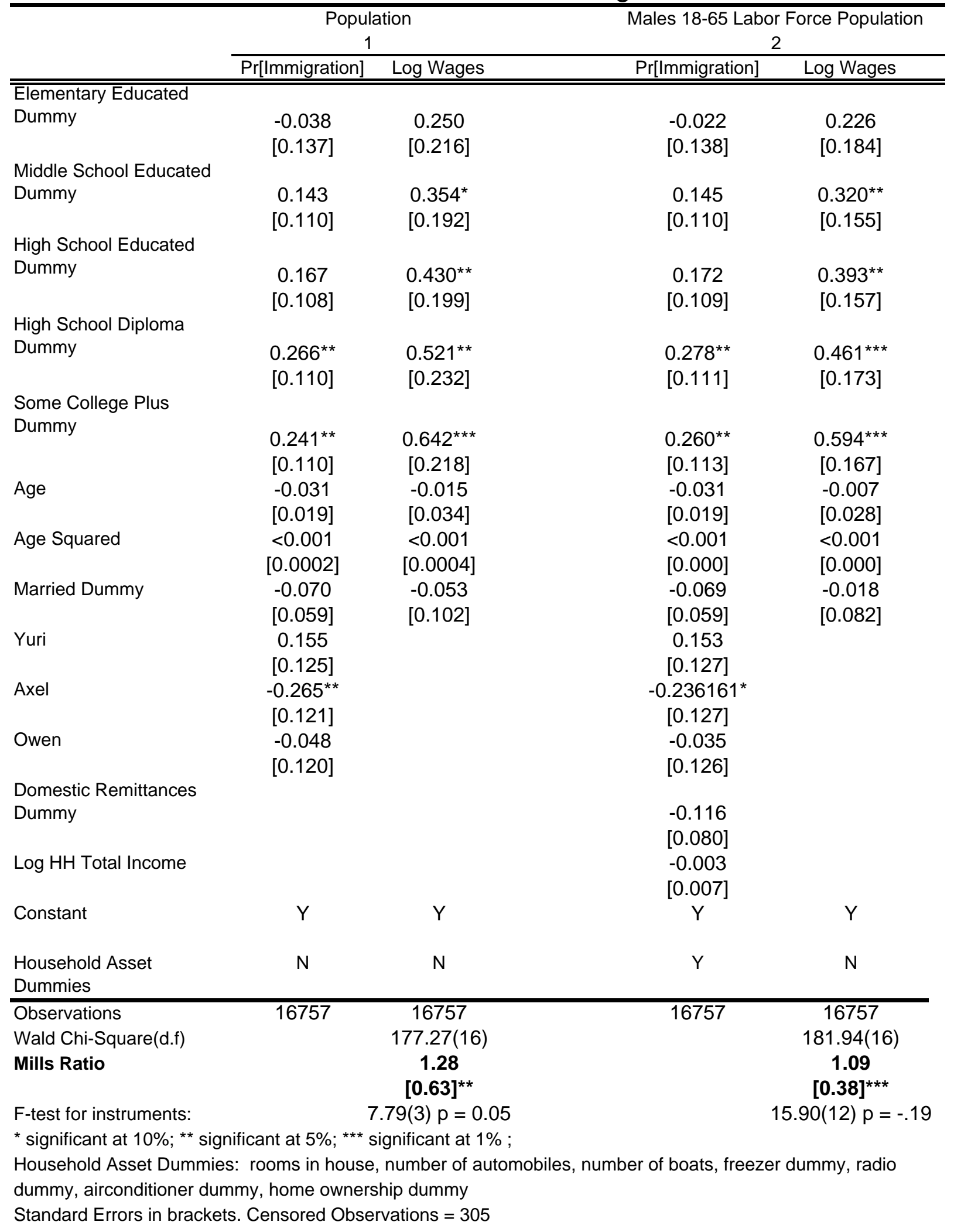


Appendix Table la: Heckman Correction using Panel Data - Males in Labor Force : Migrating for Non-Schooling Reasons

\begin{tabular}{|c|c|c|c|c|}
\hline & \multicolumn{2}{|c|}{$\begin{array}{c}\text { Total Adult Male Population } \\
1 \\
\end{array}$} & \multicolumn{2}{|c|}{$\begin{array}{c}\text { Total Adult Male Population } \\
2 \\
\end{array}$} \\
\hline & Pr[Immigration] & Log Wages & Pr[Immigration] & Log Wages \\
\hline \multicolumn{5}{|l|}{ Elementary Educated } \\
\hline Dummy & $\begin{array}{l}-0.047 \\
{[0.116]}\end{array}$ & $\begin{array}{c}0.180 \\
{[0.194]}\end{array}$ & $\begin{array}{c}-0.029 \\
{[0.117]}\end{array}$ & $\begin{array}{c}0.159 \\
{[0.131]}\end{array}$ \\
\hline \multicolumn{5}{|l|}{ Middle School Educated } \\
\hline Dummy & $\begin{array}{c}0.049 \\
{[0.094]}\end{array}$ & $\begin{array}{c}0.186 \\
{[0.158]}\end{array}$ & $\begin{array}{c}0.055 \\
{[0.094]}\end{array}$ & $\begin{array}{c}0.137 \\
{[0.105]}\end{array}$ \\
\hline \multicolumn{5}{|l|}{ High School Educated } \\
\hline Dummy & $\begin{array}{c}0.085 \\
{[0.089]}\end{array}$ & $\begin{array}{l}0.258^{*} \\
{[0.155]}\end{array}$ & $\begin{array}{c}0.095 \\
{[0.089]}\end{array}$ & $\begin{array}{l}0.199 * * \\
{[0.101]}\end{array}$ \\
\hline \multicolumn{5}{|l|}{ High School Diploma } \\
\hline Dummy & $\begin{array}{l}0.210^{* *} \\
{[0.091]}\end{array}$ & $\begin{array}{l}0.411^{\star *} \\
{[0.180]}\end{array}$ & $\begin{array}{l}0.230 * * \\
{[0.093]}\end{array}$ & $\begin{array}{c}0.290^{\star * *} \\
{[0.111]}\end{array}$ \\
\hline \multicolumn{5}{|l|}{ Some College Plus } \\
\hline Dummy & $\begin{array}{c}0.098996 \\
{[0.092582]}\end{array}$ & $\begin{array}{l}0.336997^{\star *} \\
{[0.158134]}\end{array}$ & $\begin{array}{c}0.128464 \\
{[0.094896]}\end{array}$ & $\begin{array}{c}0.272645^{\star \star \star} \\
{[0.104450]}\end{array}$ \\
\hline Age & $\begin{array}{l}-0.008992 \\
{[0.016472]}\end{array}$ & $\begin{array}{c}0.017061 \\
{[0.027371]}\end{array}$ & $\begin{array}{l}-0.010547 \\
{[0.016511]}\end{array}$ & $\begin{array}{c}0.02464 \\
{[0.018412]}\end{array}$ \\
\hline Age Squared & $\begin{array}{l}-0.000305 \\
{[0.000244]}\end{array}$ & $\begin{array}{l}-0.000811^{*} \\
{[0.000425]}\end{array}$ & $\begin{array}{l}-0.000282 \\
{[0.000244]}\end{array}$ & $\begin{array}{c}-0.000741^{* * *} \\
{[0.000282]}\end{array}$ \\
\hline Married Dummy & $\begin{array}{l}-0.069035 \\
{[0.054186]}\end{array}$ & $\begin{array}{l}-0.039774 \\
{[0.094913]}\end{array}$ & $\begin{array}{l}-0.070245 \\
{[0.054435]}\end{array}$ & $\begin{array}{c}0.008308 \\
{[0.061304]}\end{array}$ \\
\hline Yuri & $\begin{array}{c}0.014244 \\
{[0.102905]}\end{array}$ & & $\begin{array}{c}0.001494 \\
{[0.105549]}\end{array}$ & \\
\hline Axel & $\begin{array}{l}-0.183784^{*} \\
{[0.098353]}\end{array}$ & & $\begin{array}{l}-0.143604 \\
{[0.104603]}\end{array}$ & \\
\hline Owen & $\begin{array}{l}-0.142595 \\
{[0.113884]}\end{array}$ & & $\begin{array}{l}-0.148805 \\
{[0.118324]}\end{array}$ & \\
\hline \multicolumn{5}{|l|}{ Domestic Remittances } \\
\hline Dummy & & & $\begin{array}{l}-0.159291^{\star \star} \\
{[0.069909]}\end{array}$ & \\
\hline Log HH Total Income & & & $\begin{array}{l}-0.000856 \\
{[0.006580]}\end{array}$ & \\
\hline Constant & Y & Y & $\mathrm{Y}$ & Y \\
\hline $\begin{array}{l}\text { Household Asset } \\
\text { Dummies }\end{array}$ & $\mathrm{N}$ & $N$ & Y & $\mathrm{N}$ \\
\hline Observations & 21091 & 21091 & 21091 & 21091 \\
\hline Wald Chi-Square(d.f) & & $165.02(16)$ & & $175.34(16)$ \\
\hline Mills Ratio & & $\begin{array}{c}1.37 \\
{[0.49]^{\star \star *}}\end{array}$ & & $\begin{array}{c}0.9 \\
{[0.24]^{\star * *}}\end{array}$ \\
\hline F-test for instruments: & & $14.11(3) \mathrm{P}=0.002$ & & $8.22(12) \mathrm{P}=0.005$ \\
\hline
\end{tabular}

* significant at 10\%; ** significant at $5 \%$; *** significant at 1\%; Instruments are jointly significant at the $5 \%$ level (yuri, owen, axel)

Household Asset Dummies: rooms in house, number of automobiles, number of boats, freezer dummy, radio

dummy, airconditioner dummy, home ownership dummy

Standard errors in brackets 
Appendix Table lb: Heckman Correction using Panel Data - Males in Labor Force : Migrating for Non-Schooling Reasons

\begin{tabular}{|c|c|c|c|c|}
\hline & \multicolumn{2}{|c|}{$\begin{array}{c}\text { Males 18-65 Labor Force } \\
1\end{array}$} & \multicolumn{2}{|c|}{$\begin{array}{c}\text { Males 18-65 Labor Force } \\
2\end{array}$} \\
\hline & $\operatorname{Pr}[$ Immigration] & Log Wages & Pr[Immigration] & Log Wages \\
\hline \multicolumn{5}{|l|}{ 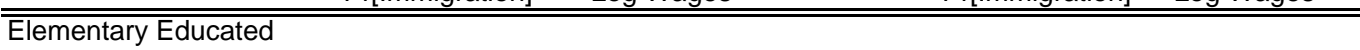 } \\
\hline Dummy & $\begin{array}{c}0.008075 \\
{[0.139736]}\end{array}$ & $\begin{array}{c}0.315753 \\
{[0.257240]}\end{array}$ & $\begin{array}{c}0.024709 \\
{[0.140186]}\end{array}$ & $\begin{array}{c}0.279279 \\
{[0.178192]}\end{array}$ \\
\hline \multicolumn{5}{|l|}{ Middle School Educated } \\
\hline Dummy & $\begin{array}{c}0.145461 \\
{[0.114133]}\end{array}$ & $\begin{array}{c}0.352657 \\
{[0.235490]}\end{array}$ & $\begin{array}{c}0.14983 \\
{[0.114662]}\end{array}$ & $\begin{array}{l}0.262091^{*} \\
{[0.152538]}\end{array}$ \\
\hline \multicolumn{5}{|l|}{ High School Educated } \\
\hline Dummy & $\begin{array}{c}0.161628 \\
{[0.112683]}\end{array}$ & $\begin{array}{l}0.411803^{*} \\
{[0.240677]}\end{array}$ & $\begin{array}{c}0.167788 \\
{[0.113322]}\end{array}$ & $\begin{array}{l}0.322489 * * \\
{[0.153371]}\end{array}$ \\
\hline \multicolumn{5}{|l|}{ High School Diploma } \\
\hline Dummy & $\begin{array}{l}0.280202^{\star \star} \\
{[0.113424]}\end{array}$ & $\begin{array}{l}0.564225^{\star \star} \\
{[0.285256]}\end{array}$ & $\begin{array}{l}0.295508^{\star *} \\
{[0.114953]}\end{array}$ & $\begin{array}{l}0.416975^{\star \star} \\
{[0.168115]}\end{array}$ \\
\hline \multicolumn{5}{|l|}{ Some College Plus } \\
\hline Dummy & $\begin{array}{l}0.230675^{\star *} \\
{[0.114231]}\end{array}$ & $\begin{array}{l}0.595056^{\star \star} \\
{[0.258551]}\end{array}$ & $\begin{array}{l}0.259713^{\star \star} \\
{[0.117131]}\end{array}$ & $\begin{array}{c}0.478239 \star \star \star \\
{[0.159688]}\end{array}$ \\
\hline Age & $\begin{array}{l}-0.018213 \\
{[0.019808]}\end{array}$ & $\begin{array}{c}0.002137 \\
{[0.038290]}\end{array}$ & $\begin{array}{l}-0.018649 \\
{[0.019890]}\end{array}$ & $\begin{array}{c}0.014293 \\
{[0.025917]}\end{array}$ \\
\hline Age Squared & $\begin{array}{c}-0.00022 \\
{[0.000292]}\end{array}$ & $\begin{array}{l}-0.000714 \\
{[0.000570]}\end{array}$ & $\begin{array}{l}-0.000213 \\
{[0.000293]}\end{array}$ & $\begin{array}{l}-0.000681^{*} \\
{[0.000391]}\end{array}$ \\
\hline Married Dummy & $\begin{array}{l}-0.057007 \\
{[0.060395]}\end{array}$ & $\begin{array}{l}-0.043747 \\
{[0.116416]}\end{array}$ & $\begin{array}{l}-0.056317 \\
{[0.060680]}\end{array}$ & $\begin{array}{l}-0.000953 \\
{[0.077233]}\end{array}$ \\
\hline Yuri & $\begin{array}{c}0.123122 \\
{[0.125248]}\end{array}$ & & $\begin{array}{c}0.120544 \\
{[0.127915]}\end{array}$ & \\
\hline Axel & $\begin{array}{l}-0.243547^{\star *} \\
{[0.121344]}\end{array}$ & & $\begin{array}{l}-0.202966 \\
{[0.127882]}\end{array}$ & \\
\hline Owen & $\begin{array}{l}-0.113511 \\
{[0.129511]}\end{array}$ & & $\begin{array}{l}-0.098629 \\
{[0.134972]}\end{array}$ & \\
\hline \multicolumn{5}{|l|}{ Domestic Remittances } \\
\hline Dummy & & & $\begin{array}{l}-0.109611 \\
{[0.081956]}\end{array}$ & \\
\hline Log HH Total Income & & & $\begin{array}{l}-0.003191 \\
{[0.007648]}\end{array}$ & \\
\hline Constant & Y & Y & Y & Y \\
\hline $\begin{array}{l}\text { Household Asset } \\
\text { Dummies }\end{array}$ & $\mathrm{N}$ & $\mathrm{N}$ & Y & $\mathrm{N}$ \\
\hline Observations & 16765 & 16765 & 16765 & 16765 \\
\hline Wald Chi-Square(d.f) & & 142.38(16) & & 148.5(16) \\
\hline Mills Ratio & & $\begin{array}{c}1.5 \\
{[0.73]^{\star \star}}\end{array}$ & & $\begin{array}{c}1.03 \\
{[0.33]^{\star * \star}}\end{array}$ \\
\hline F-test for instruments: & & $7.79(3) p=0.05$ & & $18.58(12) P=0.09$ \\
\hline
\end{tabular}

* significant at $10 \%$; ** significant at $5 \%$; *** significant at 1\%; Instruments are jointly significant at the $5 \%$ level (yuri, owen, axel)

Household Asset Dummies: rooms in house, number of automobiles, number of boats, freezer dummy, radio

dummy, airconditioner dummy, home ownership dummy

Standard errors in brackets 
Appendix Table Ila: Heckman Correction using Panel Data : Males in Labor Force and 25 years or older

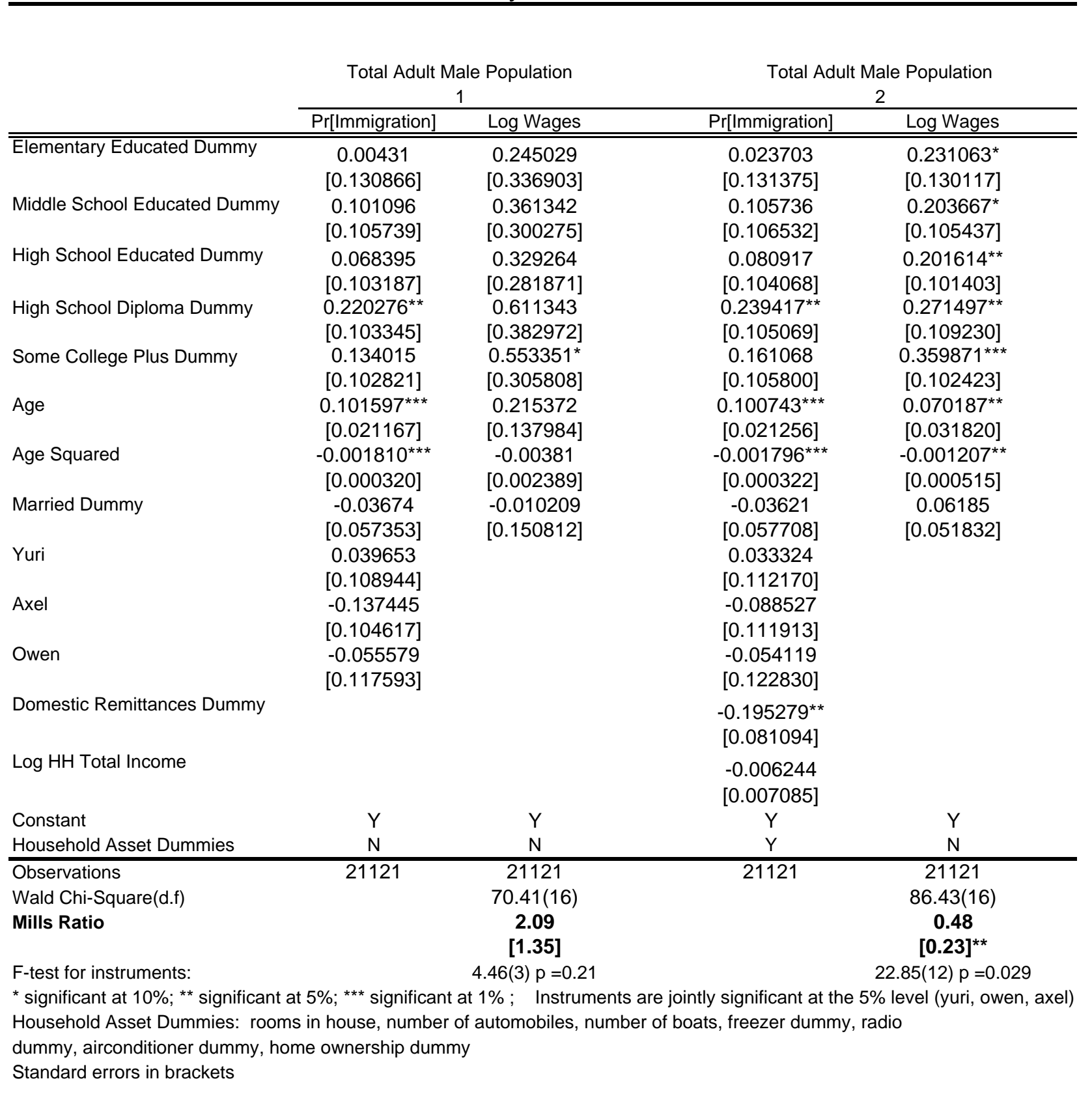


Appendix Table Ilb: Heckman Correction using Panel Data : Males in Labor Force and 25 years or older

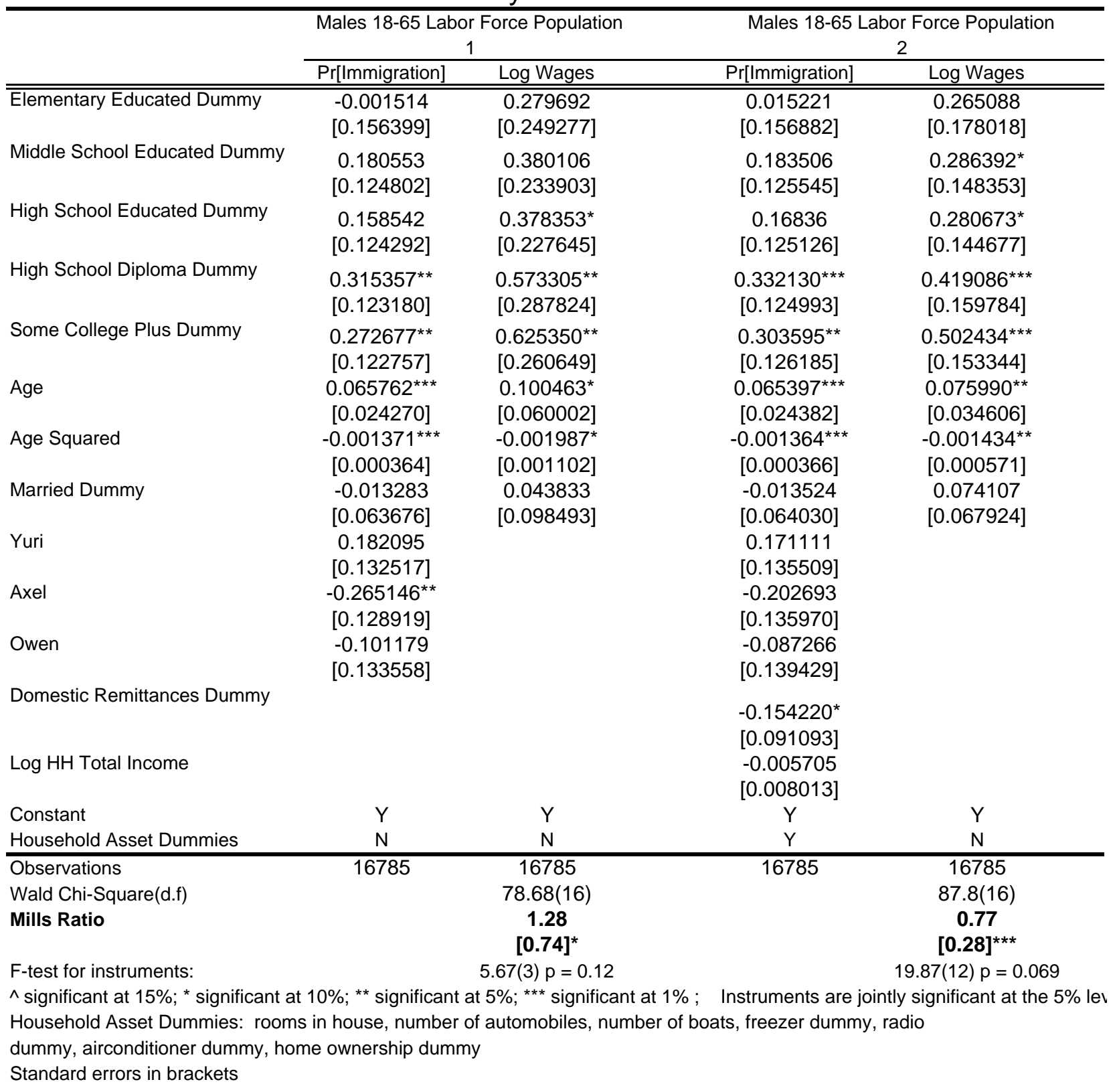

